NESIF $85-3100$

\title{
Literature Survey on Drop Size Data, Measuring Equipment and Discussion of the Significance of Drop Size in Fire Extinguishment
}

Warren D. Hayes, Jr.

U.S. CEPARTMENT OF COMMERCE

National Zureau of Standarcs

National Engineering Laboratory

Gaithersbure, AD 20899

January : 935 

NBSIR $85-3100$

$\cdots$

LITERATURE SURVEY ON DROP SIZE

DATA, MEASURING EQUIPMENT AND

DISCUSSION OF THE SIGNIFICANCE OF

DROP SIZE IN FIRE EXTINGUISHMENT

Warren D. Hayes, Jr.

U.S. DEPARTMENT OF COMMERCE

National Bureau of Standards

National Engineering Laboratory

Gaithersburg, MD 20899

January 1985

Prepared for:

U.S. Federal Emergency Management Agency

Washington, DC

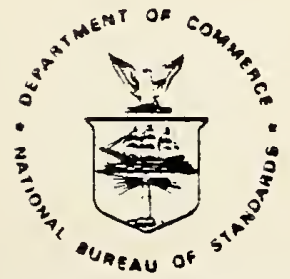

U.S. DEPARTMENT OF COMMERCE, Malcolm Baldrige, Secretary NATIONAL BUREAU OF STANDARDS. Ernest Ambler, Director 

TABLE OF CONTENTS

$\underline{\text { Page }}$

Abstract $\ldots \ldots \ldots \ldots \ldots \ldots \ldots \ldots \ldots \ldots \ldots \ldots \ldots \ldots \ldots \ldots \ldots \ldots \ldots \ldots \ldots \ldots \ldots \ldots \ldots \ldots \ldots \ldots \ldots . . \ldots$

1. INTRODUCTION $\ldots \ldots \ldots \ldots \ldots \ldots \ldots \ldots \ldots \ldots \ldots \ldots \ldots \ldots \ldots \ldots \ldots \ldots \ldots \ldots \ldots \ldots$

2. LITERATURE SEARCH $\ldots \ldots \ldots \ldots \ldots \ldots \ldots \ldots \ldots \ldots \ldots \ldots \ldots \ldots \ldots \ldots \ldots \ldots \ldots \ldots \ldots \ldots . \ldots . \ldots$

2.1 The Search for Existing Data ...................... 3

2.2 The Search for Measurement Apparatus ................. 4

3. BACKGROUND MATERIAL ................................ 8

3.1 Mechanisms of Extinguishment and the Effect of Firefighting Techniques........................ 8

3.2 Dynamics of Extinguishment $\ldots \ldots \ldots \ldots \ldots \ldots \ldots \ldots \ldots \ldots \ldots \ldots \ldots \ldots \ldots$

4. REFERENCES ....................................... 19

5. ADDITIONAL READINGS .................................. 20

APPENDIX .......................................... 25 

LITERATURE SURVEY ON DROP SIZE DATA, MEASURING EQUIPMENT AND

DISCUSSION OF THE SIGNIFICANCE OF DROP SIZE IN FIRE EXTINGUISEMENT

Abstract

The literature was searched for information and data on the slze of water droplets from fire fighting equipment, on instrumentation and techniques for measuring droplet size in dense sprays, and on the signiffcance of droplet size in water sprays used for fire extinguishment. Included is a discussion of droplet size information from an impinging jet type fire hose nozzle. Droplet size analyzers that use shadowgraphic technique are likely to be best sulted for measuring sprays from fire hose nozzles. The effects of droplet size in water sprays used for extinguishment in confined and unconfined spaces and with and without counterflowing air currents are discussed.

\section{INTRODUCTION}

The purposes for this literature search are: (1) to obtain information and data on the size of water droplets issued from fize fighting equipment with emphasis on 1-1/2 inch fire hose nozzles as a step toward providing inputs needed for modeling manual fire extinguishment, and (2) to obtaln information and data on how to measure drop sizes in dense sprays in antictpation of the need for additional data. This literature search was iniltated with computer searches of the following indexes, the descriptions of which are in the appendix: 

(1) INSPEC - Information Services in Physics, Electrotechnology, Computers and Control

(2) NTIS - National Technical Information Service

(3) BHRA - British Eydromechanics Research Association

(4) COMPENDEX - The Englneering Index

(5) TRIS - Transportation Research Information Service

\section{(6) POLAB - Pollution Abstracts}

The computer search was followed by manual searches of the Engineering Index for the years 1955 through 1969 to complement the computer search of COMPENDEX, The BuIlding Research Establishment References to Scientific Literature on Fire for the years 1950 through 1980, and the NBS Fire Research Information Service subject file. Lastly, telephone discussions were held with the following: two staff people in college fire protection curriculum, three people on the NFPA fire hose committee, two technical people with companies manufacturing hose nozzles, two federal fire researchers outside of NBS, a fire researcher in the Building Research Establishment in England, two federal aerodynamic engineers, and several people in industzy doing droplet analyses and droplet measuring research.

As a result of the index searches and telephone discussions, nine books, twenty-six reports, thirty-four articles, and two standards were identified 
and revlewed. Only those discussed are cited, but the remainder are lacluded In the bibliography.

\section{LITERATURE SEARCH}

\subsection{The Search for Existing Data}

The search for existing data on droplet size of sprays from fire hose nozzles yielded only one document, the sumary of which follows. Savage and Freeman [1] reported the results of their drop size measurements in sprays from nozzles used in the extlnguishment of fully developed room fire tests of Hifd [2]. The fog nozzles were of the impinglng jet type. This means that the nozzle was designed to direct pairs of jets to coll1de exterfor to the nozzle to form the spray. The aforementioned nozzles were operated at 552 , 1551 and $3147 \mathrm{kPa}(80,225$ and $500 \mathrm{psi})$ pressure and wh flow rates of 1.14 , 3.41 and $5.68 \mathrm{~m}^{3} / \mathrm{s}(5,15$ and $25 \mathrm{gpm})$. The orffice size was held constant at 1.59 ming ( $1 / 16 \mathrm{in})$, and therefore, the flow rate was varted by changtng the number of patrs of jets. The rechnique for determintag drop size was coe of collecting samples at selected points in the spray pattern in shallow glass dishes containlng a layer of castor oil, waking contact photographs of the dishes filled with droplets, projecting the photographs for enlargement, and measuring the image sizes with a template.

The following table was extracted from their report. The ralues are weighted for volume distribution of the water withla the overall spray patter from the nozzle. 


$$
\text { Mass-Median Drop Size ( } \mu \mathrm{m})
$$

Flow $\left(\mathrm{m}^{3} / \mathrm{s}\right)$

1.14

3.41

5.68
Pressure ( $\mathrm{kPa})$

\begin{tabular}{l}
$552 \quad 351+3147$ \\
\hline
\end{tabular}

550

390

320

850

620

610

540

590

540

Unfortunately, the nozzle here characterized is not of a type commonly used for fighting fires in the United States. Most of the fog nozzles used in this country generate droplets by impaction of the hose stream with a plate within the nozzle.

The technical people working for fire hose nozzle manufacturing companies who were contacted by telephone did not reveal any results of drop size distribution measurements they have taken on their own nozzles or others.

\subsection{The Search for Measurement Apparatus}

The search for information on droplet size measurement apparatus was much more fruitful. The recent interest in energy conservation has intensified resarch in the measurement of droplet size and velocity even more so than did spray drying in previous years. Spray drying is a process that has been found very useful for generating many powdered materials such as instant coffee from solutions. The interest in droplet size related to energy conservation is in the development of fuel spray nozzles for improved combustion efficiency. The 
Interest in such spray characteristics is not just of recent times, but rather a revival prompted by more recent 1mprovements in measurement technology. Jones [3] wrote a comprehensive review of the methods for measuring droplet size in dense fuel sprays, which he defined as droplet concentrations in excess of one drop per cubic millimeter. He described most of the known mechanical, electrical and optical methods. The mechanical methods include droplet capture on slides coated with powders, or in pools of imiscible liquids like that used by Savage and Freeman [1], cascade 1mpactors, freezing, and sedimentation, the electrical methods include gapped electrodes, charged Wres and hot wire anemometers and the optical wethods include high speed photography, holography and laser defraction. Pffty references are cited.

Azzopardi [4] subsequently published a much more comprehensive review in which he divided the droplet size measurement methods into the following categories: photographic, impact, thermal, electrical, optical, time of residence, and indlrect via veloctty. He further tabulated the nethods with regard to their characteristics which included whether they provided number or mass flux data, single particle or cloud average counting, size distribution or mean size, and temporal or spatial distribution. The size range, disadvantages, advantages and references for each method are given. One hundred and thirty-one references are cited.

Chigier [5] followed with an extremely comprehensive review of drop size and velocity 1nstrumentation. The main focus of this review however, was on optical methods such as holography, laser doppler anemometry (LDA) and laser transit anemometry (ITA). It also discussed a phase discininating sampling probe that withdraws samples isokinetically and even briefly mentloned st111 
and motion photography, and high speed video. Forty-five references are cited.

Not mentioned in any of these reviews but worthy of note is the work of Semiat [6] who simplified the formation of a laser bean interference fringe pattern with use of a Ronchi grid. A Ronchi grid is a glass plate with equally wide alternating clear and opaque lines. When the grid is placed in a laser beam, the identical pattern is transmitted. An interesting feature of this technique is that crossed grids allow for the measurement of two-dimensional velocities.

It is evident from the number of fundamentally different methods of measuring droplet size here mentioned that there are numerous pieces of apparatus in existance. Improvements in signal acquisition and processing and miniaturization of computers have greatly simplified the process of obtaining droplet analyses of sprays. Even one of the oldest methods, photography, has attracted new interest because of the advent of tmage analyzers which digitize video images. Many of the pieces of apparatus were, however, not studied in detail by this author simply because they lacked provision for or because of the anticipated complextty of providing protection of the electronic and optical elements from the enviroment accompanying the production of sprays produced by some of the equipment of interest. The reader is reminded that Euel sprays for internal combustion engines are only a few hundred cubic centimeters in volume, and therefore very different from sprays that fill entire rooms for fire extinguishment. As one would expect, tradeoffs must be made. 
Equipment that w111 measure drop size distributions of sprays from aerosol cans usually will not do so for sprays from fire hose nozzles and vice versa. Holographic equipment will capture action in very large volumes of space but obtalning a droplet size distribution analysis from the hologram is very laborious. The hologram like a 35 m camera slide must be used to reconstruct (project) with use of a laser light source the captured image into space. The reconstructed object must then be manually analysed with use of a telescopic type lens system with a drop sizing raticule and this must be done plane by plane through the volume. Equipment that will analyse clouds of drops by use of Fourter transform lens focussing of diffraction patterns from each drop in the cloud onto a specially patterned detector is very good for quickly obtaining drop size averages from fairly large volumes of spray. This type of equipment does not, however, allow one to view the drops being measured or to obtain drop velocities. Shadowgraphic equipment that automatically w11 perform the laborious process of calcularing the droplet size distributions usually will do so for only a small slice of the spray patterns at a time, and therefore, one must systematically take many samples of the whole pattern or part of the pattern for symetrical sprays. The size of the volune 1ato which the sample can be placed also is important when one way want to include sources such as flames and hot surfaces that generate counterflows that would interact with extiaguishment sprays.

Drop analyzers that use the shadowgraph technique, with a strobe l1ght source and video monitoring and recording of 1ndividual drops are probabiy best suited for studying water sprays from fire fighting equipment. Inages from Individual drops ranging in size from 8 to 10,000 un may be 1 lg1tized and then sized and counted as directed by accompanying soitware which then can 
analyze the data and provide arithmetic, surface, volume, weight and Sauter mean diameters and size distributions. The addition of a multiple strobe feature can also provide the capability of obtaining droplet velocity data. Furthermore, it has been demonstrated to measure droplets immersed in propane flames.

\section{BACKGROUND MATERIAI}

3.1 Mechanisms of Extinguishment and the Effect of Firefighting Techniques

Water probably has been the primary fire extingulshant used by man since he learned to use fire. The delivery of water for the extinguishment of unwanted fires has changed over the gears from hand transportation in buckets to flow through hoses supplied by pumps. The form of the water used has changed from bucketfuls to sprays. For many years between the use of bucketfuls and the use of sprays, solid hose streams were used. Thus the main topic related to extinguishment in the fire literature of this period was the transport of water from its source to the fire at a suffictent rate and in sufficient quantity. Nothing was said about the form of the watar delivered. Sprays as opposed to solid streams re used but only in automatic sprinkler systems and only for the purpose of distributing the water throughout the space for which the protection was designed rather than for the benefit provided by the state of division of the water.

The earliest discussion advocating the use of sprays consisting of very small droplets of water for manual firefighting was by Lloyd Layman [7] who in 1954 originated the "indirect method of fire attack". The method was devised as a result of experiments in the extinguishment of fuel oil fires in merchant 
marlne ship machinery spaces. Layman directed these experiments during World War II at which time he was Commandant of the U.S. Coast Guard Fire Fighting School. The method proposed that sprays consisting of very swall water droplets be infected into confined spaces containing fires. The conclusion drawn from the test results was that the rapid generation of stean within a confined space created a vlolent atmospheric disturbance within the space. Put a little differently, the rate of evaporation is directly proportional to surface area of the water that is exposed to the heat and for a given volume of water is inversely proportional to the droplet diameters squared. Therefore, the smaller the droplets, the higher the rate of evaporation. The evaporation of water absorbs $2.26 \times 10^{3} \mathrm{MJ} / \mathrm{m}^{3}(8100 \mathrm{Btu} / \mathrm{gal})$ and is accompanied by a volume expansion of approximately 1700 times the original. The rate and magnitude of the expansion of the water to steam apparently creates great turbulence which contributes to the distribution of the remaining droplets of water to much of the remaining heat in a confined space. The steam displaces a large volume of the air required to sustain combustion in the space and consequently the fire is suppressed.

The National Board of Fire Inderwrters [8] subsequently supported a nore detailed investigation of the use of finely divided water at the Underviliss Laboratory. For this investigation a test chamber with an approximately one square meter base and approximately txo meters in height was constructed of galvanized steel with a removeable top, adjustable vents and a spray port on the sides near the bottom. Nineteen spray nozzles were characterfzed for droplet size distribution at various water pressures and at vartous distances from the nozzle. Test fires using $237 \mathrm{ml}$ of gasoline, kerosene, or ethyl alcohol were burned in sheet metal pans approximately 150 square by 50 or 
$150 \mathrm{~mm}$ deep or $300 \mathrm{~mm}$ square by $300 \mathrm{meep}$ placed on the floor of the chamber. Fires of small wood piles also were included in the tests. Water sprays from each or some combination of the nineteen nozzles were directed toward the fires from approximately 3 m directly above or horfzontally through the side port approximately 250 mobove the floor.

The conclusions were as follows: (1) That these flamable liquid fires were extinguished predominately by dilution of the air supply with water vapor. (2) Up to a point, reducing the droplet size of the water spray is beneficial. (3) Sprays directed down from directly above with droplet diameters less than 150 um did not extinguish the fires because they were repelled by the fire plume. (4) The same sprays were effective when directed from the side. (5) There was a definite increase in the amount of water required when the droplets were larger than $300 \mu \mathrm{m}$. (6) Confining the fire to the burn compartment was a very important factor in the effectiveness of the water spray. (7) Wood fires had a strong tendency to rekindle after the spray was stopped.

Several investigators subsequently conciuded that the mechanism of extinguishment of diffusion flames in other than the confined spaces used in the Layman and the National Board of Fire Underwiter Tests was by cooling of the fuel. Bryan's [9] tests of the extinguishment of wood cribs demonstrated that the resistance to extinguishment depended more on the heat content of the fuel than on the rate at which it was generating heat. Rasbash [10] concluded from his extinguishment experiments with pool and wood fires that the best way to extinguish a fire was to assure that the water reach and cool the fuel. Be also stated that for wost fires the droplet size of the spray was not usually 
an Important factor. He did acknowledge that it was not clear whether room fires were more efficiently controlled by cooling of the fuel or by cooling of the flames. He belleved that investigations up to that time had not been sygtematic enough to allow one to draw conclusions about how the extingulshment mechanisms operate during real room firas. Lacking were data on critical flow rate and quantity of water required.

It is obvious from the aforementioned works that different fire situations require different fire fighting tactics. Cooling of the fuel is the surest method for most situations, but smothering by the displacement of afr with water vapor is very effective under certain conditions which have been characterized only as confined. Droplet size must be important because the droplet must have enough momentum to overcome the resistance over the path that it travels and because in many situations it must not evaporate before it reaches the fuel. The waterspray path is dependent upon the available access to the fire, the available equipment, and the firefighter's choice of attack position. The firefighter's preference for position of attack would be upwind of the fire so that the smoke and heat would be blown away from him and so that the wind would help carry the water spray to the fire. Furthermore, the usual technique for applying water to a fire, excluding the situation of 3 ifre in a confined space, would be to direct the spray at the base of the fire. As the base of the fire recede as the near part of the fuel is extinguished, the spray would be directed to follow it with due consideration of the burning characteristics of other fuel in the direction that the fire was being chased. The latter simply alludes to the fact that air entrained in the spray tends to blow the fire, persisting beyond the area of spray impaction, in the direction of the spray, and that the firefighter Mll not 
Intentionally cause the fire to be blown toward highly flammable material if 1t can be avoided. The same consideration would apply to trapped occupants. For intense fires in confined spaces, the technique used initially might be to direct the spray to the upper part of the space from a low level opening. Since the hot gases from a fire tend to concentrate near the ceiling in a confined space, this tactic assures that the maximum amount of water is converted to vapor, a process which absorbs heat and displaces smoke and thereby provides better visability of and accessability to the base of the fire. This type of fire is frequently underventilated, lacking oxygen, when extinguishment is begun and has been known to flash when air currents created by air entrainment in the spray have ventilated the fire. In both of these situations, travel of the spray would probably be aided rather than impeded by currents of atr. If however, the wind were to change, or simultaneous attack from other positions chase the fire toward the firefighter, or the firefighter be forced by inaccessibility of a better position to take a position requiring directing of the spray counter to the fire plume, the spray stream would have to be strong enough to overcome the counterflows. Dynamics of sprays are covered in the next section of this report.

\subsection{Dynamics of Extinguishment}

The relationship between spray momentum and gaseous counterflows has been discussed by several authors. The earliest discussions related to the process called spray drying, a technique for converting solutions or slurries into powders. Lapple and Sheppard [11] published a comprehensive theoretical, mathematical analysis of particle trajectories in a variety of air streams. The interest in this case was in suspending droplets in an air stream for the time required for them to crystallize or dry. 
Kalelkar [12], Yao [13], Dundas [14], Lfu [15] and Begler [16] theorized about the interaction of spray droplets and fire plumes as related to automatic sprinklers. All of these authors based their discussions on a balance of forces relationship between a moving droplet and a moving alr stream. For the simple case where the drop is falling straight down through an alr stream moving straight up the balance of forces may be expressed as follows:

$$
\text { m } \frac{d v_{d}}{d t}=m g-\frac{\rho_{s} C_{D} A_{d} v_{d s}^{2}}{2}
$$

where $m=$ mass of the drop $(\mathrm{kg})$

$v_{d}=$ velocity of the drop $(m / s)$

$t=\operatorname{time}(s)$

$g=$ acceleration of gravity $\left(\mathrm{m} / \mathrm{s}^{2}\right)$

$\rho_{s}=$ density of the air stream $\left(\mathrm{kg} / \mathrm{m}^{3}\right)$

$C_{D}=$ drag coefficient of drop

$$
=f\left(N_{R e}\right)=f \frac{D_{d}{ }^{v} d s^{0} s}{H_{s}}=0.44[11]
$$

$$
\begin{aligned}
& \text { for } 500<N_{R e}<200,000 \text { where } D_{d}=\text { dlameter of drop (I) } \\
& \mu_{s}=\text { viscosity of air stzeam } \\
& \text { ( } \mathrm{kg} / \mathrm{m}-\mathrm{s})
\end{aligned}
$$


$A_{d}=$ largest cross sectional area of drop normal to air stream $\left(m^{2}\right)$

$v_{d s}=$ velocity of drop relative to air strean $(m / s)$

Solving for $v_{d}$ in fire extingulshment sprays is difficult for the following reasons:

1) The motion of the droplets in fire extinguishment is a three-dimensional problem rather than the one-dimensional problem given as the simple case. The thrust of the fire driven air current varies threedimensionally with location and conditions in the compartment fire even without the disturbing forces that accompany extinguishment. Furthermore, the conditions vary as the characteristics and location of the burning fuel involved change with the progression of the fire.

2) The approximation of the drag coefficient previously given was determined from experiments with single drops rather than the dense clouds of spray associated with extinguishment. One would expect that in a dense spray many drops would be in the wake of others and that the drag in such a situation would be different from that for a single drop, but such a determination apparently has not been made. Of course, evaporation from the many drops in the cloud would raise the water vapor level in the cloud which in turn would reduce the rate of evaporation from the drops wich does have an effect on drag. Drag on drops has two components, friction drag and pressure drag. Yuen [17] found that evaporation from water drops always reduces the friction drag. The pressure drag is not affected by evaporation at Reynolds numbers below 20, but at that point it begins to 
Increase with Reynolds muber. Be determined that the increase in pressure drag wil equal the decrease in friction drag when the Reynolds number reaches 1000 resulting thereafter in increasing total drag. Bvaporation also reduces the size of the drop wich reduces the cross section of the drop and thereby reduces the drag.

3) The cross section of the drop varies in flight because the sinape of the drop oscillates between a teardrop and horizontal ellipsoid. This instability is worse for larger drops.

The spray from a sprinkler is probably the most extreme interacilon of an extingufshant and a fire driven counterflow and, therefore, the wost dificul to predict. The reason is that the active sprinkler usualiy is to the side of the vertical axis of the fire where the plume is the strongest.

Thomas and Rasbash have done studies on the characteristics of spraps from fize hose nozzles. Thomas [18] derived a formula for predicting the throw of spray from a fire hose nozzle in the absence of wind Erom data taken From a NEPA report [20]. The formula is as follows:

$$
t=2.32+0.85=+2.15 a \div 0.36 p+1.03=a
$$

where $=\log _{10}$ throw (m)

$=\log _{10}$ flow rate $\left(\mathrm{m}^{3} / \mathrm{s}\right)$

$a=\log _{10} \frac{\tan (\operatorname{total} \text { sprap cone angle) }}{4}$ 


$$
\mathrm{p}=\log _{10} \frac{\text { pressure }(\mathrm{KPa})}{100}
$$

Rasbash [19] discussed penetration of spray to the "seat of the fire" as affected by drop size, thrusts of the spray and of the fire plume, the wind, and gravity. For example, the critical spray "thrust" (i.e. its spray momentum per unit area at the flame) to just penetrate the flame from above was suggested by Rasbash [19] to be related to the flame height as follows:

$$
T_{c}=0.5 \circ \mathrm{gx}
$$

where $\mathrm{T}_{\mathrm{C}}=$ critical thrust $\left(\mathrm{N} / \mathrm{m}^{2}\right)$

$$
\begin{aligned}
& \rho=\text { density of air }\left(\mathrm{Kg} / \mathrm{m}^{3}\right) \\
& g=\text { acceleration due to gravity }\left(\mathrm{m} / \mathrm{s}^{2}\right) \\
& x=\text { height of flame prior to spray (m) }
\end{aligned}
$$

One can then use the following relationship between flame height and heat release rate as determined by McCaffrey [21] to determine this critical thrust in terms of heat release rate: 


$$
x=0.2 Q^{2 / 5}
$$

where $x=$ flame height (m)

$$
Q=\text { heat release rate }(\mathrm{kW})
$$

Rasbash [19] also determined that the spray thrust from a nozzle was related to reaction of the nozzle in the following manner.

$$
\text { Spray thrust }=\mathrm{R} / \mathrm{A}=\mathrm{CP} \mathrm{P}^{0.5} \mathrm{~F} / \mathrm{A}
$$

where $R=$ nozzle reaction force

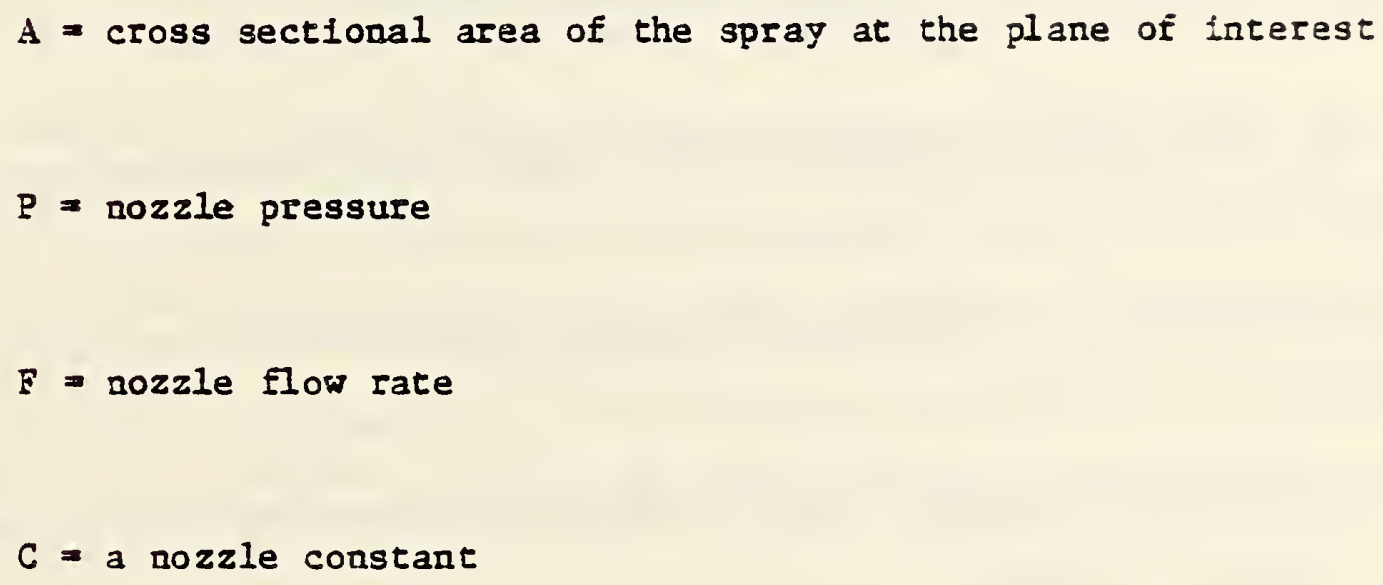

He also made the very interesting statement that the spray thrust was entrely converted to momentum of the entrained air stream within about six feet of the spray nozzle. Purington [22] gives a relationship to estinate spray nozzle reaction in terms of flow rate. The above relattonships gfve some sense of the factors influencing the dyamics of water sprays in fires. 
The extinguishment of room fires is a very complex phenomenon. The literature suggests that the strategy for the majority of fires should be to cool the fuel rather than smother the flame. This is in spite of the fact that most unwanted fires are already in a ventilation controlled stage when extinguishment is begun $[23,24]$. Water must reach the fuel to cool it. Most of the theoretical and experimental work thus far has dealt with penetration of the fire plume by water spray. This itself is a very complex problem because of the variability encountered in the burning characteristics and arrangement of combustible furnishings, the ventilation characteristics of the space, the difficulty of dealing with the three-dimensional motion of both the droplets in the water spray and the fire driven counter air currents, and the reaction of the fire to the extinguishment process.

To apply existing knowledge of extinguishment dynamics to real life fire fighting requires more information on the drop size and velocity distributions from hose nozzles. This report identifies available techniques for the measurement of nozzle spray characteristics, and contains a literature bibliography on the subject, and on the research studies of the dynamics of water sprays on flames. 
[1] Savage, N., and Freeman, S., The determination of the drop sizes of high and low pressure water sprays. F.R. Note No. 373/1959, Flre Research Station, Borehamwood, Herts, 9 p.

[2] Hird, D., Plckard, R. W., Fittes, D. W., and Nash, P., The use or high and low pressure water sprays against fully developed room fires. F. R. Note, No. 388/1959, Fire Research Station, Borehamwood, Berts, 23 p.

(3) Jones, A. R., A review of drop size measurement - The application of techniques to dense fuel sprays, Prog. Energy Combustion Science, Vol. 3, Pergamon Press, (1977) pp 225-234.

[4] Azzopard1, B. J., Measurement of drop sizes, Int. J. Heat Mass Iransfer, Vol. 22, Pergamon Press, Ltd., (1979) pp. 1245-1279.

(5] Chigier, N., Drop size and velocity instrumentation, Prog. Energy Combust. Sci., Vol. 9, Pergamon Press, (1983) pp. 155-177.

[6] Semiat, R., and Dukler, A. E., Simultaneous measurement of size and velocity of bubbles or drops: a new optical technique, A. I. Ch E Jour, Vol. 27, No. 1, (Jan. 1981) pp 148-159.

[7] Layman, L., Attacking and extinguishing interior fires, National Bize Protection Association, Boston, Mass., Third Edition, (1958) 149 p.

[8] The mechanism of extinguishent of fire by finely divided water, NBFU Research Report, No. 10, National Board of Fire Underwriters, N. $Y$. (1955) $73 \mathrm{p}$.

[9] Bryan, J., The effect of chemicals in water solution on fire extinction, Engineering, pp. 457-460, June 1945, p. 474, June 15, 1945, pp. 497-500, June $22,1945$.

[10] Rasbash, D. J., Rogowski, Z. W., and Stark, G. W. V., Mechanisws of extinction of Iiquid fires with vater sprays, Combustion and Flame, (1960) pp. 223-234.

[11] Lapple, C. E. and Snepherd, C. B., Calculation of particle trajectortes, Industrial and Engineering Chemistry, Vol. 32, No. 1, (Yay 1940) Pp. 605-617.

[12] Ralelkar, A. S., The dynamics of large deforming liquid drops in stzong vertical afr-streams, FMRC Ser. No. 18792, Factory Wutual Research Corporation, Norwood, MA (Apr11 1970) 19 ?.

[13] Yao, C. and Ralelkar, A. S., Effect of drop size on spriakler performance, Fire Technology, (November 1970) po. 254-268.

[14] Dundas, P. H., Cooling and penetration study, FMRC Ser. No. 18792, Factory Mutual Research Corporat1on, Norsood, MA (May 1974) 56 p. 
[15] Liu, S. J., Analytical and experimental study of evaporative cooling and room fire suppression by corridor sprinkler system, Nat. Bur. Stand. (U.S.) NBSIR 77-1287; (1977 November) 56 p.

[16] Beyler, C. L., The Interaction of fire and sprinklers. Nat. Bur. Stand. (U.S.) NBS-GCR-78-121; (1977 September) 78 p.

[17] Yuen, M. C. and Chen, L. W., Dynamics of evaporating water droplets, NU-ME/AS No. 75-1, Northwestern University, Evanston, IL (May 1975) 24 p.

[18] Thomas, P. H. and Smart, P. M. T., The throw of water sprays, F. R. Note No. 168, Fire Research Station, Borehamwood, Herts, England, (May 1955) 3 p.

[19] Rasbash, D. J., The extinction of fires by water sprays, Fire Research Abstracts and Reviews, Vol. 4, January and May 1962, Nos. 1 and 2, pp. 28-53.

[20] Out of print and not available, Studies of fire department fog nozzles, National Fire Protection Association, 1952.

[21] McCaffrey, B. J., Purely buoyant diffusion flames: some experimental results, Nat. Bur. Stand. (U.S.) NBSIR 79-1910, (1979 October) 49 p.

[22] Purington, R. G., Fire fighting hydraulics. New York: McGraw-Hill Book Company; (1974) p. 371 .

[23] Fire Protection Handbook, Nat'1 Fire Protection Assn., Boston, MA, 14th Ed Section 2-16 (1976).

[24] Fried, Emanuel, Chapter 6, Ventilation, in Fireground Tactics, H. Marvin Ginn corp., Chicago, IL. (1972).

\section{BIBLIOGRAPHY}

Ahmadzadeh, J. and Harker, J.H., Evaporation from liquid droplets in free fall, Transactions of the Institution of Chemical Engineers, Vol. 52, (1974) pp. 108-111.

Bachalo, W.D., Hess, C.F. and Hartwell, C.A., An instrument Ior spray droplet size and velocity measurements, Transactions of the ASME, Vol. 102, (October 1980) pp. 798-806.

Briffa, F.E., Transient drag in sprays, Eighteenth Symposium on Combustion, The Combustion Institute, (1981) pp. 307-319.

Cadle, R.D., Introduction in the measurement of afrborne particles, John Wiley and Sons, New York, NY (1975).

Cassatt, W.A. and Maddock, R.S., Editors, Aerosol measurements, Nat. Bur. Stand (U.S.) Spec. Publ. 412, (October 1974), 412 p. 
Clift, R. and Gauvin, H.甘., Motion of entrained particles in gas streams, The Canadian Journal of Chemical Engineering, Vol. 49, (August 1971) pp. 439-448.

Dombrowski, N. and Fraser, R.P., A photographic investigation into the disintegration of liquid sheets, Philisophical Transactions, V01. 247 , A929 (1954) pp. 101-142.

Fire Protection Bandbook, Natl. Fire Protection Assn., Boston, MA, 15 Edition, Sections 14-81, 16-80, (1981).

F1re Stream Practices, IFSTA 105, Edited by Eudiburg, E., Characteristics of good fire streams, p. 37, Design and construction of fire stream nozzles, p. 161, Fire Protection Publications, Oklahoma State University, Stillwater, OR (1972).

Fraser, R.P. and Dombrowsk1, N., The dependence of interpretation on photographic technique in fluid kinetics research, Proceedings of the Third International Conference on Bigh Speed Photography, London, (September 1956) pp. 376-384.

Freeman, J., Experiments relating to hydraulics of fire streams, Transactions of the American Society of Civil Engineers, Paper No. 426, Vo1. XXI, p. 303, (November 1889).

Fuchs, P., On the extinguishing effect of various extinguishing agents and extinguishing methods with different fuels, Fire Safety Journal, $i$ (1984) pp. 165-175.

Glantschnig, W.J., Golay, M.W., Chen, S. and Best, F.R., Light scattering device for sizing and velocimetry of large droplets utilizing a ring-shaped laser beam, Applied Optics, Vol. 21, No. 13, (July 1982) pp. 2456-2460.

Hewitt, G.F. and whalley, P.B., Advanced optical instrumentation methods, Int. J. Multiphase Flow, Vol. 6, Pergamon Elsevier, England, (1980) pp. 139-156.

Hickey, B., Evaluation of discharge straam projections from two selected nozzles at minimum angle elevations, NP 73-1, Natl. Fize Procection Assn., Boston, MA.

Hickey, \#., Flow through orifices, Chapter 2, Suppression equ1pment discharge analysis, Chapter 6, in Iydraulics for fire protection, Vatl. Fire Protection Assn., Boston, MA (1980).

Hird, D., Plckard, R.W., Fittes, D.W. and Vash, P., The use of high and low pressure water sprags against fully developed room E1res, Fire Research Note No. 342, (1958), 21 p.

Hughes, R.R. and Gilliland, E.R., The mechanics of drops, Chemlcal Engineering Progress, Vol. 48, No. 10, (October 1952) pp. 497-504. 
Irani, R.R. and Callis, C.F., Definitions, Chapter 2, Methods of data presentation, Chapter 3, Distribution functions applicable to particle size distributions, Chapter 4, In particle size measurement, interpretation and application, John Wiley and Sons, New York, NY (1963).

Rumano, Y., Repeated tracking method for cinematographic study of fire stream disintegration, Proceedings of the Third International Congress on High Speed Photography, London (September 1956) pp. 389-391.

Kung, Hsiang-Cheng and Hill, J.P., Extinction of wood crib and pallet fires, Combustion and Flame, Vol. 24, (1975) pp. 305-317.

Layman, L., Fire fighting tactics, Nat1. Fire Protection Assn., Boston, MA (1953) 108 p.

Murakami, M. and Katazama, K., Discharge coefficients of fire nozzles, Transactions of the ASME, (December 1966), pp. 706-716.

Pietrzak, L.M. and Patterson, W.J., Effect of nozzles on fires studies in terms of flow rate, droplet size, Fire Engineering, Vol. 132, No. 12, (Dec. 1979) pp. 26-28,33.

Polymeropoulos, C.E. and Sernas, V., Measurement of droplet size and fuel-air ratio in sprays, Combustion and Flame, Vol. 29 (1977) pp. 123-131.

Radusch, K., Observations on the most favorable size of drops for extinguishing fires with atomized water and on the range of a stream of water spray, Karlsruhe Polytechnical Institute (1953) 18 p.

Radusck, R., On the evaporation rate of water drops, Chemical Engineer Technics, Yearbook 28, (1956) pp. 275-277.

Rasbash, D.J., The properties of sprays produced by batterfes of 1mpinging jets, F.R. Note No. 181 (1955), Fire Research Station, Borehamwood, Herts, England, 7 p.

Rasbash, D.J., The relative merits of high and low pressure water sprays in the extinction of liquid fires, Fire Research Note 199 (1955), Fire Research Station, Borehamwood, Berts, England.

Rasbash, D.J. and Stark, G.W.J., Some aerodynamic properties of sprays, Fire Research Note No. 445 (1960), Fire Research Station, Borehamwood, Herts, England.

Ranz, W.E. and Hofelt, C., Jr., Determining drop size distribution of a nozzle spray, Industrial and Engineering Chemistry, Vol. 49, No. 2, (February 1957) pp. 288-293.

Reitz, R.D. and Bracco, F.V., Brakup regimes of a single liquid jet, Eastern States Section of the Combustion Institute at Drexel University (November 1976). 
Rouse, H., Howe, J.W. and Metzler, D.E., Experimental Investigation of fire monitors and nozzles, American Society of Civil Engineers, Transactions Paper 2529, pp. 1147-1188.

Seleznev, Y.S., Sen, L.I. and Yefimov, V.V., A method for determining droplet size distributions in two phase flows, Fluld Mechanfes - Soviet Research, Vol. 9, No. 6, (Nov-Dec 1980) pp. 127-132.

Standard for Automotive Fire Apparatus, Natl. Fire Code No. 1901, Vol. 12, Nat1. Fire Protection Assn., Boston, MA (1982).

Standard for Safety, UL 401, Portable spray hoze nozzles for fire protection service, Underwriter Laboratories, Northbrook, IL (1978) 10 p.

Stark, G.W.U., Some measurements of the velocities of drops in water sprays, Fire Research Note No. 302 (1957), Fire Research Station, Borehamwood, Herts, England.

Tamanini, F. , A study of the extinguishment of vertical wood slabs in self-sustained burning by water spray application, Combustion Science and Technology, Vol. 14 (1976) pp. 1-5.

Tamantinf, F., The application of water sprays to the extinguishment of crib fires, Combustion Science and Technolgoy, Vol. 14 (1976), pp. 17-23.

Theobald, C.R., A photographic technique for the study of water jets, Fire Research Note No. 1041, (September 1975), Fire Research Station, Borehamwood, Eerts, England.

Theobald, C., The effect of nozzle design on the stability and performance of turbulent water jets, Fire Safety Journal, Vol. 4 (1981) pp. 1-13.

Thomas, P.A. and Smart, P.M.T., Fire extinction tests in rooms, Fire Research Note No. 121 (1954), Fire Research Station, Borehamwood, Jerts, England.

Thornas, P.N. and Smart, P.M.T., The extinction of fires in enclosed spaces, Fire Research Note No. 66 (1954) 22 p.

Thompson, N.J., Fire behavior and sprinklers, Natl. F1re Protection Assn., Boston, MA (1964) 157 p.

Trolinger, J.D., Analysis of holographic diagnostics systems, Optical Engineering, Vo1. 19, No. 5 (Sept/Oct 1980) p. 722-726.

You, H., Sprinkler drop-size measurement, Part II: An invest1gat1on of the spray patterns of selected commercial sprinklers with the FMRC PMS droplet measuring system, Factory Mutual Research Corporat1on, Norwood, MA (May 1983) 95 p. 
You, H. and Symonds, A.P., Sprinkler drop-size measurement, Part I: An investigation of the FMRC PMS drop-size measuring system, Factory Mutual Research Corporation, Norwood, MA (December 1982) 57 p. 
APPENDIX

\section{Computer Indexes}

1. INSPEC (Information Services in Phystcs, Electrotechnology Computers and Control) corresponds to the three Science Abstracts printed publications. Electrical and Blectronics Abstracts, Computer and Control Abstracts, and Physics Abstracts.

2. NIIS (Dialog Information Retrieval Service) The database consists of government sponsored research, development, and engineerfing reports as well as other analyses prepared by government agencies, their contractors or grantees.

3. BHRA (British Hydromechanics Research Association) contains records from the ten BHRA - produced abstract journals and other sources providiag a comprehensive source of information on all aspects of fluid engineering and behavior and application of fluids.

4. COMPENDEX (The Englneering Index) contains abstracted information Erom the worlds' significant engineerfing and technological literature.

5. TRIS (Transportation Research Information Service) is a composite file whose records are either abstracts of documents and data hold1ngs, or resumes of research projects that are relevant to the planning, development, operation, and performance of transportation systems and their components. 
6. POLAB (Pollution Abstracts) is a leading resource for references to enviromentally related technical literature on pollution, its sources and its control. The database corresponds to the printed Pollution Abstracts, 
NBS. IILA IREV. 2A0)

U.S. DEPT. OF COMM.

1. PUBLICATION OR REPORT NO.

BIBLIOGRAPHIC DATA

SHEET (See inseructions)

NBSIR $85-3100$

2. Performing Organ. Repore Nod 3. Publicasion Date

January 1985

4. TITLE AND SUBTITLE

Literature Survey on Drop Size Data, Measuring

Equipment and Discussion of the Significance of Drop Size in

Fire Extinguishment.

5. AUTHOR(S)

Warren D. Hayes, Ir.

6. PERFORMING ORGANIZATION (If joint of other than NBS, see in structions)

7. Contracd Grant No.

MATIONAL BUREAU OF STANDARDS

DEPARTMENT OF COMMERCE

WASHINGTON, O.C. 20234

8. Type of Report \& Period Cove

9. SPONSORING ORGANIZATION NAME AND COMPLETE ADDRESS (Street, City, StOte, ZIP)

U. S. FederaI Emergency Management Agency

Washington, DC

20024

10. SUPPLEMENTARY NOTES

Document describes a computer program; SF-185. FIPS Software Summary, is attached.

11. ABSTRACT (A 200-word or less foctual summory of most significont information. If tocument includes a significont bibliogrophy or literoture survey. mention it here)

The literature was searched for information and data on the size of water droplets from fire fighting equipment, on instrumentation and techniques for measuring droplet size in dense sprays, and on the significance of droplet size in water sprays used for fire extinguishment. Included is a discussion of droplet size information on an impinging jet type fire hose nozzle.

Droplet size analyzers that use shadowgraphic technique are likely to be best suited for measuring sprays from fire hose nozzles. The effects of droplet size in water sprays used for extinguishment in confined and unconfined spaces and with and without counterflowing air currents is discussed.

12. KEY WORDS (Six to tweive entries; olphobetical order: copitolize only proper nomes; and seporote key woras zy semicolon s drop size measurements; fire extInguishent; fire fighting; fire hoses; room Eires; spray nozzles; water

13. AVAILABILITY

Unlimized

For Official Distribution. Do Not Release to NTIS

Order From Superintendent of Documents, U.S. Government Printing Office, 'Nashington. D.C. 20402.

Z Order From National Tectnical Information Service (NTIS). Soringfield, VA. 22161

14. NO. OF PRINTED PAGE

31

15. Peics 
. 

